\title{
人間とロボットの協調作業系における作業動特性の干渉制御を実現する 動特性調節器の開発および評価*
}

\author{
木下 敦之 ${ }^{* 1}$, 積際 徹 ${ }^{* 2}$, 横川 隆一 ${ }^{* 2}$
Development and Evaluation of Mechanical Regulator of Dynamical Interference in Human-Robot Cooperative Task System

\author{
Nobuyuki KINOSHITA ${ }^{* 1}$, Toru TSUMUGIWA and Ryuichi YOKOGAWA \\ ${ }^{* 1}$ Doshisha Univ., Dept. of Biomedical Engineering \\ Tatara-Miyakodani 1-3, Kyotanabe-city, Kyoto, 610-0321 Japan
}

\begin{abstract}
This paper presents development and evaluation of a mechanical regulator and a robot motion control scheme for a human-robot cooperative task system. There are contact stability problems that a control system becomes unstable when the robot using impedance control comes into contact with a stiff environment in human-robot interactions. The proposed robot motion control system enables stable contact with the stiff environment by the proposed regulator. The proposed regulator is developed to adjust the dynamical interference between object inherent dynamics and robot dynamics, and it provides dynamics transparency to a human operator in human-robot dynamics cooperation. The regulator is composed of mechanical load adjuster to transmit the human force to the robot and motion measuring system that detects relative positional deviation data between the human arm tip and a tip of the robot. To confirm the stability of the proposed control system, stability analysis simulations and verification experiments using an arm robot are performed. A human-robot cooperative experiment shows that effectiveness of the proposed system for increasing the stability and the dynamics transparency in human-robot physical interactions.
\end{abstract}

Key Words : Human-Robot-Interaction, Robot, Man-Machine System, Contact Stability Problem, Motion Control, Impedance Control

\section{1. 緒言}

現在, 人間とロボットの物理的相互作用に関する研究が盛んに行われており ${ }^{(1)(2)}$, それらの研究におけるロボッ トの運動制御法としてインピーダンス制御が広く用いられる ${ }^{(3)}$ (9). しかし，一般的なインピーダンス制御では, 操作者および作業対象物（以降，操作者および作業対象物を「操作者」に統合する）とロボットが剛に結合され ており，両者の動特性はロボットに設定されるインピーダンス特性（慣性・粘性・岡性）に干渉され，拘束され てしまう.このため, ロボットと接触する環境が高剛性の場合に, ロボットの制御システムが不安定になるといっ た問題が生じる(10) (13). この問題に対して，(i) ロボット手先に設定されるインピーダンス特性の粘性を大きくす る方法 ${ }^{(10)(14)}$ ，(ii）ロボットの運動制御法を自由空間と拘束空間で切り替えるスイッチングシステム ${ }^{(15)}$, (iii) 外部 環境と接触時に外部環境接触力から求まる指令速度を修正しロボットの安定接触を実現する方法 ${ }^{(16)}$, (iv) 受動性 の概念を用いたロボットの制御法などが提案された ${ }^{(17)}$.しかし，これらには，粘性を大きくすることで操作者の 負担が大きくなる問題や(10)(14), 実際のロボットを用いた際の安定性について解析的に明らかにされていないこと ${ }^{(14)(16)}$ に加えて, 一部の研究においては, 外部環境接触力から求まる指令速度を修正することによって操作者が外 部環境の動特性を感じる（認識する）ことができなくなり，操作者が作業に対して直感的な操作を行うことがで

\footnotetext{
* 原稿受付 2013 年 3 月 31 日

${ }^{* 1}$ 同志社大学大学院 生命医科学研究科（广610-0321 京都府京田辺市多々羅都谷 1-3）

$*_{2}$ 正員, 同志社大学 生命医科学部 医工学科

E-mail: ttsumugi@mail.doshisha.ac.jp
} 
きないなどの問題があった ${ }^{(16)}$.

本研究では, 従来のインピーダンス制御において岡にに結合された操作者とロボットの動特性の干渉具合を調節 し, 両者の動特性を非干渉化する動特性調節器（以降，調節器とする），および，調節器を用いたロボットの運動 制御法を開発することを目的とする．操作者がロボットに加える力に応じたインピーダンス制御と，操作者手先 の動きにロボットが追従する制御を組み合わせることで，高剛性環境に対する接触安定問題が解決できるだけで なく，同時に，接触作業における外部環境の動特性を操作者が直接的に感じることが可能になる.

提案する調節器と制御法の働きにより, 操作者とロボットを物理的に切り離して, 両者を非干渉化（あるいは 低干渉化）することで，操作者は作業対象物と外部環境本来の動特性に基づいた接触作業を実現することができ る. 作業対象物と外部環境が持つ固有の動特性に従う運動により, 操作者は外部環境に対する運動感覚的な透明 性 ${ }^{(18)}$ 感じることができる. 従来のインピーダンス制御では, 設定するインピーダンス特性の帯域内の動特性し か感じることができず (インピーダンス特性が動特性に関するローパスフィルタのような働きをするため), 感覚 に基づく技能の発現が難しくなっていた，提案システムでは， ロボットの運動と操作者の動特性が非干渉化され るため，作業者は直接的に作業対象物に関わる動特性を感じ取ることが可能になる．このため，精密な組立作業 や感覚的な技能の発現が必要となる精緻な作業など, 人間の持つ作業技能に基づいて行う必要のある作業への適 用が可能になり，仮想的な動特性に従う運動を生成していたインピーダンス制御では実現できなかった作業への 応用が期待できる.さらに, 動特性の非干涉化によって高剛性環境下でも安定した制御を実現できる.この場合, 操作者とロボットの間で力学的協調関係が消失寸ることから (両者間で力伝達ができないため), インピーダンス 制御の利点であるパワーアシスト効果が失われたり，都合の良い動特性を仮想的に付与寸ることができなくなる が，作業の遷移状態に応じて両者の干渉具合（力伝達量）を適宜調節寸ることで，干渉化・非干渉化それぞれの 利点を使い分けることが可能である．人間とロボットの協調作業に関する従来の研究において，上述のような干 渉制御を実施しつつロボットの運動制御を行う研究はこれまでになかったことから, 本研究では調節器の開発お よび評価を行い，インピーダンス制御をベースとした新たな制御法の確立を目指す.

本研究では，まず，操作者とロボットの干涉具合の調節を行うことで，両者間の力伝達を機構的に調節し，同 時に両者間の相対的な位置偏差を検出する機構を有した調節器の開発を行う. 次に, 提案調節器を用いて, ロボッ 卜手先に加わる力とロボットと操作者間の位置偏差をインピーダンスモデルへの制御入力とする制御法の提案を 行う. 提案システムの安定性を解析的に明らかにするため, 運動制御システムのモデル化を行い, 数值シミュレー ションによる安定解析を行う. 次に, 安定解析の検証のため, 多自由度ロボットを用いた実験を行い, 解析結果 と比較する. 最後に, 調節器の効果を確認するため, 外部環境との接触を伴う人間とロボットの力学的協調作業 を行い，提案システムが高剛性環境下でも安定して作業を行うことが可能であること，ならびに，操作者が外部 環境の動特性を感じることが可能になることを示寸.

\section{2. 提案システムおよび提案調節器}

\section{$2 \cdot 1$ システムの概要}

本研究のシステム概要を図 1 に示寸. 7 自由度を有するロボット（三菱重工業製 PA-10）の手先に力覚センサ (ニッタ製 IFS-67M25A50-I40）が取り付けられており，その上に提案調節器が配置される．作業対象物は調節 器上部（ハンドル部）に搭載される．操作者は調節器を介してロボットを操作する. 提案システムでは, 操作者 とロボットが結合された従来のインピーダンス制御を行うことが可能であることに加えて (図 1 (a)), 調節器の 働きによって操作者とロボットを機構的に切り離すことができるため（ロボット手先位置 $\boldsymbol{p}_{R}$ と操作者手先位置 $p_{S}$ の位置偏差 $\Delta \boldsymbol{p}$ が生じる), 両者の動特性を非干渉化した状況下において, 操作者手先の動きにロボットが 追従する制御（ロボットが位置偏差 $\Delta \boldsymbol{p}$ をゼロにしようとする運動：図 1 （b））を実現することができる．従来の 類似研究として, RCC デバイスなどの柔軟な受動要素をロボットの手先に配置する手法があるが(19)(20)，この場合

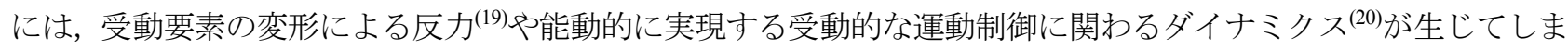
うため, 操作者とロボットを機構的・物理的に切り離すことはできない. 本研究において提案する調整器では, 機構的・物理的に両者を切り離すことが可能となり，両者の非干涉化を実現できる．なお，本研究において，口 ボット制御のサンプリングタイムは $2 \times 10^{-3}$ 秒である. 


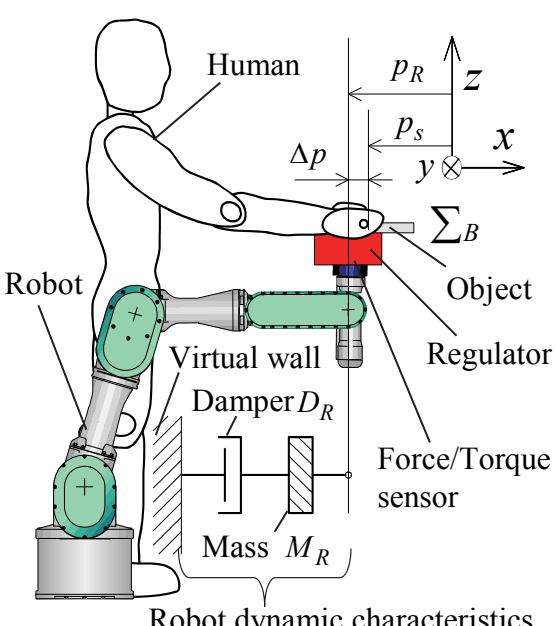

Robot dynamic characteristics

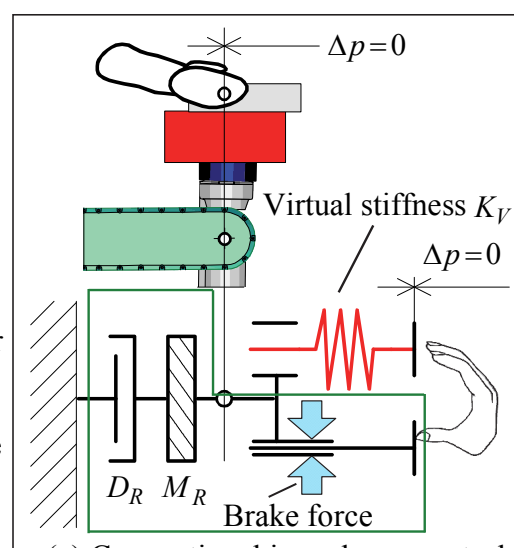

(a) Conventional impedance control

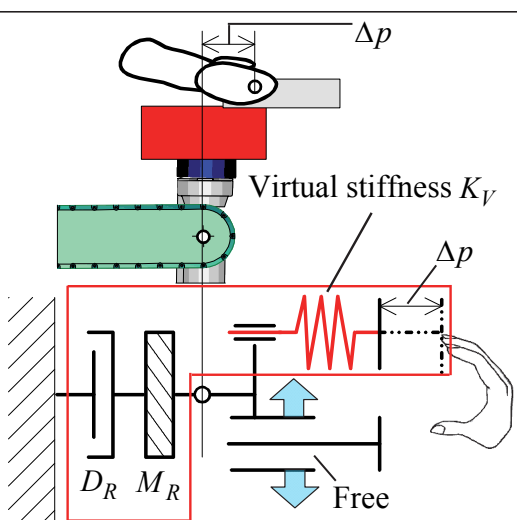

(b) Motion control without interference between object dynamics and robot dynamics

Fig.1 Overview of proposed motion control system

\section{$2 \cdot 2$ 動特性調整器の概要}

提案調節器の概要を図 2 および図 3 に示す. 調節器は, リニアガイドレールを用いた受動的に摺動する機構（直 交 3 軸方向への摺動が可能）を持つ（図 2)，操作者手先とロボット手先間の相対的な位置偏差を検出する位置検 出機構と, 受動要素であるレールの摺動に摩擦負荷を与えるブレーキ機構（力伝達量調節機構）によって構成さ れ, 操作者手先 $\boldsymbol{p}_{s}=\left[p_{s x}, p_{s y}, p_{s z}\right]^{T}$ とロボット手先位置 $\boldsymbol{p}_{R}=\left[p_{R x}, p_{R y}, p_{R z}\right]^{T}$ の位置偏差 $\Delta \boldsymbol{p}=\left[\Delta p_{x}, \Delta p_{y}, \Delta p_{z}\right]^{T}$ を レーザセンサによって検出する (図 3)。ささらに, 操作者がロボットに加える力 $\boldsymbol{F}_{H}=\left[F_{H x}, F_{H y}, F_{H z}\right]^{T}$ は調節器の 直下に設置される力覚センサによって検出される. また, リニアガイドレールに取り付けられたブレーキ機構に より摩擦負荷を与えることで, 操作者とロボット間の干渉具合を調節することができる (図 2). 図 3 は $x-z$ 平面 に関するものであるが, $y$ 軸方向に関する調節器の構成も同様である. 本研究では, 調節器のハンドル部の運動 が直交 3 軸の並進運動に限られるため, ロボットの運動についても同様の運動に限定し, 回転方向は考慮しない ものとする.

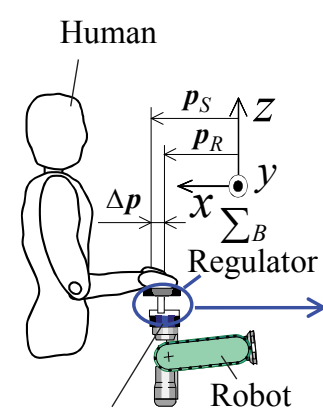

Force/Torque sensor

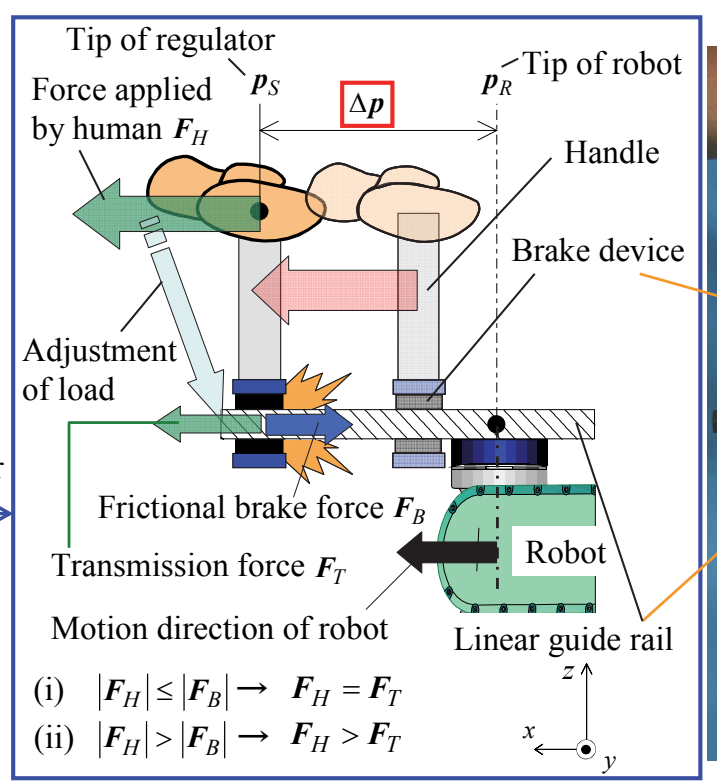

Aluminum frame

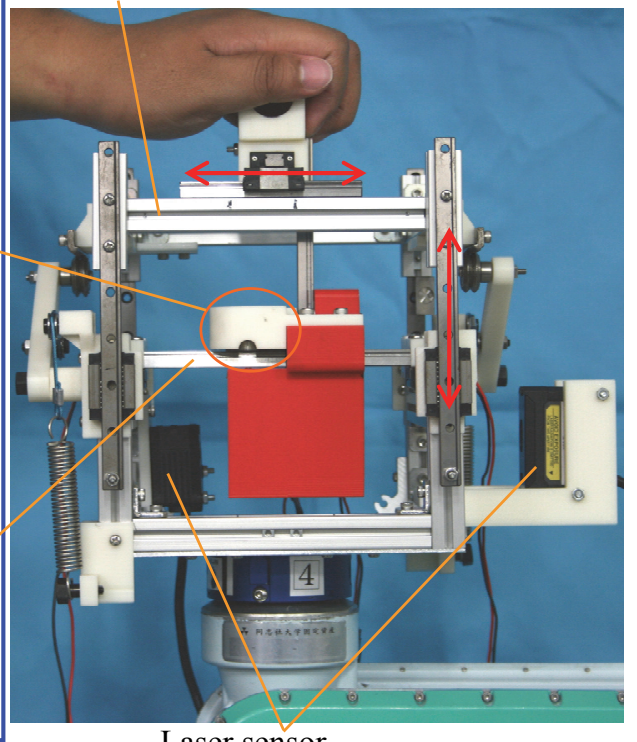

Laser sensor

Fig.2 Overview of proposed mechanical regulator 


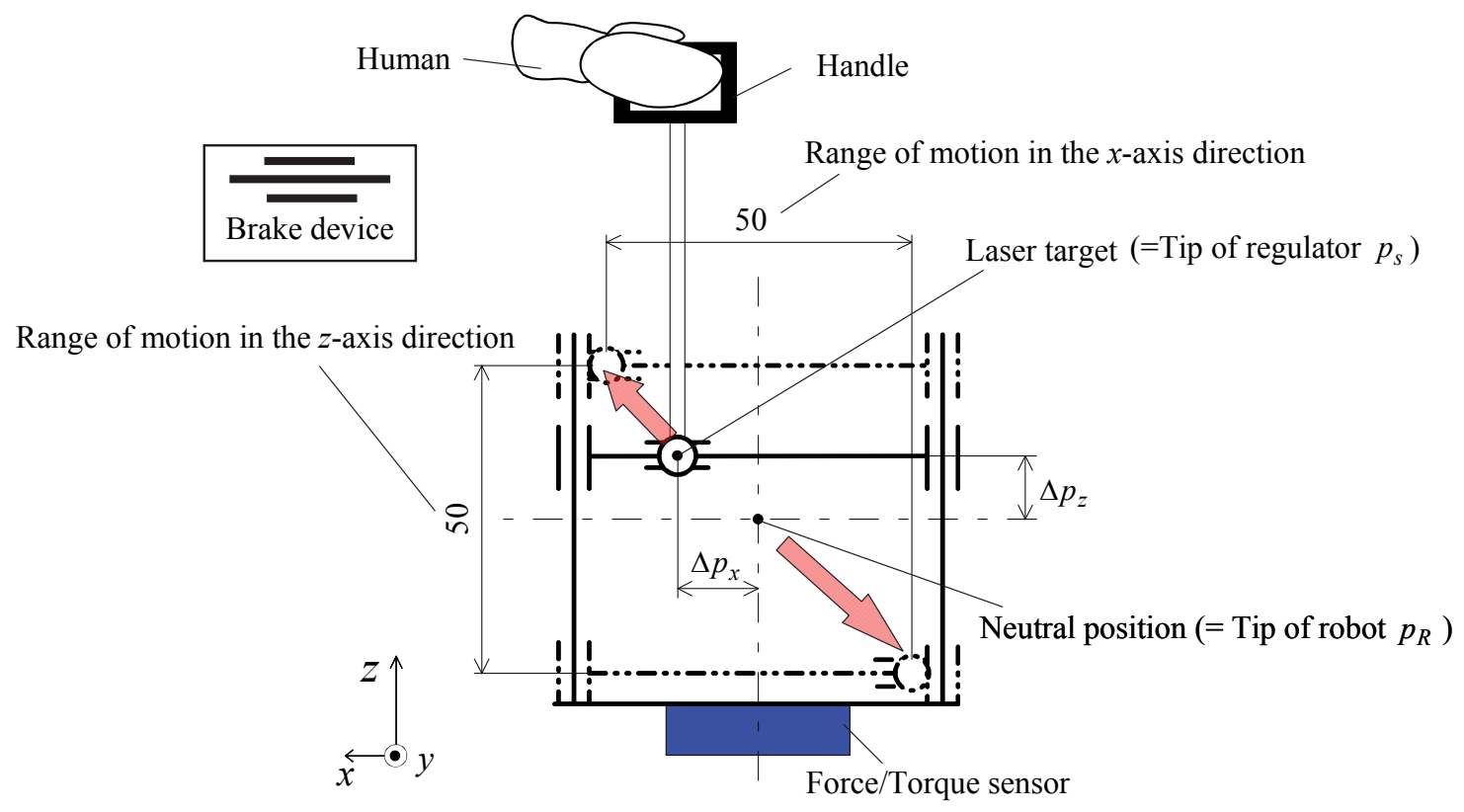

Fig.3 Schematic drawing of motion of proposed mechanical regulator

\section{$2 \cdot 3$ 位置検出機構}

位置検出機構は操作者手先とロボット手先の相対変位を計測するものであり，水平方向と鉛直方向の直交 3 軸 方向の受動部を有する機構である. 受動要素には滑らかな摺動を行うために 3 軸共にリニアガイドレールを用い ている. 操作部の可動域は 3 軸共に $50 \mathrm{~mm}$ （中立位置から $\pm 25 \mathrm{~mm}$ ）である（図 3). 操作者手先位置 $\boldsymbol{p}_{s}$ とロボッ ト手先位置 $\boldsymbol{p}_{R}$ の位置偏差 $\Delta \boldsymbol{p}$ はレーザセンサ（センサヘッド KEYENCE 製 IL-065，アンプユニット KEYENCE 製 IL-1000）により直接読み取ることができ，以下の式のようにセンサの出力電圧 $\boldsymbol{E}=\left[E_{x}, E_{y}, E_{z}\right]^{T}$ から位置偏 差量に変換することができる.

$$
\Delta \boldsymbol{p}=\left[\Delta p_{x}, \Delta p_{y}, \Delta p_{z}\right]^{T}=k\left[E_{x}, E_{y}, E_{z}\right]^{T}
$$

ここで, $k$ は電圧から偏差量に変換するための校正係数である. レーザセンサの検出精度は $0.012 \mathrm{~mm}$, サンプリ ングタイムは $1 \times 10^{-3}$ 秒である.

\section{$2 \cdot 4$ 力伝達量調節機構}

提案調節器において, 操作者とロボットが機構的に切り離され, 両者の動特性が非干渉化されると, 両者の力 学的協調関係が消失寸る. つまり, その際に操作者からロボットのインピーダンスモデルに力を伝えることがで きない. そこで, 調節器の受動要素であるリニアガイドレールに摩擦特性を与え, 操作者とロボット間の干渉具 合を調節することによって, 操作者からロボットに伝わる力の調節を実現する. 本研究では, これを力伝達量調 節という。提案機構では，リニアガイドレール上に電磁石（ギガテコ製 TNM208S）を複数個設置し，レールに 摩擦力を与えるブレーキ機構として用いた。制御 PC から DA ボードとアンプを介して電磁石に電圧を与え, 発 生する摩擦力を制御する. 摩擦力は $2 \sim 10 \mathrm{~N}$ まで調節することが可能である. この摩擦力によって, 操作者が口 ボットに与える力（操作者からロボットに伝達される力）を調節することができる.

\section{3. ロボットの運動制御則}

力覚センサで検出された力 $\boldsymbol{F}_{H}$ と, 提案調節器によって検出された操作者とロボット手先間の位置偏差量 $\Delta \boldsymbol{p}$ に $3 \times 3$ 対角行列の仮想剛性係数 $\boldsymbol{K}_{V}$ を乗じた力 $\boldsymbol{K}_{V} \Delta \boldsymbol{p}$ を仮想力としてインピーダンスモデルに入力し, ロボットは 
これらの入力を減少するように運動制御される，本研究において，ロボット手先の目標インピーダンスを次式の ように設定した.

$$
\boldsymbol{M}_{R} \ddot{\boldsymbol{p}}_{R}(t)+\boldsymbol{D}_{R} \dot{\boldsymbol{p}}_{R}(t)=\alpha \boldsymbol{K}_{V} \Delta \boldsymbol{p}(t)+(1-\alpha) \boldsymbol{F}_{H}(t)
$$

ここで， $\boldsymbol{p}_{R}$ はロボットの手先位置 $[\mathrm{m}]$ であり， $\boldsymbol{M}_{R}, \boldsymbol{D}_{R}$ はそれぞれ慣性係数 $[\mathrm{kg}]$, 粘性係数 $[\mathrm{Ns} / \mathrm{m}]$ を表す $3 \times 3$ 対 角行列である． $\alpha$ は力覚情報と位置偏差情報の制御入力としての重み係数[-]である.このときのロボットの運動 制御モデルのブロック線図を図 4 に示寸，仮想力 $\boldsymbol{K}_{V} \Delta \boldsymbol{p}$ は，位置偏差量 $\Delta \boldsymbol{p}$ の大きさに応じて仮想的に生成する 入力であり，提案システムでは力の次元を持つ量として仮想的な物理量として取り扱う。なお，図 4 にはロボッ トの手先位置における理想的な運動制御モデルを示しており，後述する図 5 および図 6 で考慮しているロボット のコンプライアンスモデルは考慮していない.

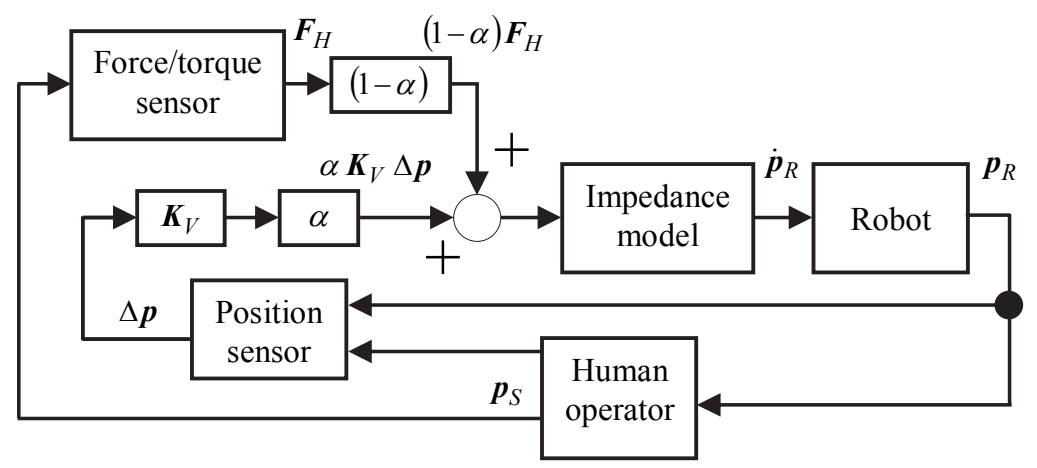

Fig.4 Block diagram of proposed robot motion control

提案制御法では, 制御入力の重み $\alpha$ およびブレーキ力の変更によって, 以下のような制御を実現することがで きる (図 1(a), (b)参照).

(i) $\alpha=0$

力覚センサで検出される力覚情報 $\boldsymbol{F}_{H}$ のみが制御入力となり, 力覚情報に基づくインピーダンス制御が実現さ れる.このとき, 図 1 (a) において, ブレーキ力が最大になることでロボットと操作者は力学的に直結（岡に結 合）され，両者間に生じる力は全てロボットの制御入力となる．なお，操作者手先の運動によるレールの滑り， つまり, 操作者手先とロボット手先の位置偏差 $\Delta \boldsymbol{p}$ は生じない.

(ii) $\alpha=1$

位置偏差による仮想力 $\boldsymbol{K}_{V} \Delta \boldsymbol{p}$ のみが制御入力となり, 操作者手先の運動によるレールの滑りが生じ, 操作者手 先の運動にロボットが追従する制御が実現される。このとき, 図 1 (b) において, ブレーキ力はゼロであり, 操 作者とロボットが切り離され，両者の動特性が非干涉化されるので，両者間の力学的協調関係は消失する.

(iii) $0<\alpha<1$

上述の制御状態の中間状態が実現される.レールが適度に滑るようにブレーキ力を調整し，摩擦力を伴いなが ら操作者とロボット手先間の位置偏差ならびに相互作用力が生じる.

\section{4. 安定解析のためのロボット運動制御システムのモデル化}

本章では, インピーダンス制御をベースにした式 (2) の提案制御則に関する安定性を明らかにするために, 操 作者の影響も含めた， ロボット手先の運動に関わる制御システムのモデル化を行う.ロボット手先のインピーダ ンス特性は, $x, y$ および $z$ 座標軸それぞれに独立して与えられ，各軸同士の力および運動の干渉がなく，回転 運動を考慮しないので, 安定解析には 1 自由度の並進運動についてのモデル化を行う.

ここで, 仮想力を除いた, 実際の力学的な関係を示した力学モデルを図 5 に示す. ロボットの動特性はインピー ダンス特性によって表す，同様に，操作者および外部環境の動特性，ロボットのコンプライアンスの影響によっ て生じる動特性は，慣性と剛性によって表す。なお，粘性については同定が困難であることから無視し 0 とする 
が，粘性を 0 とした場合には，解析結果がより危険側（不安定側）に振れるので，結果に関して安全率がかかる という利点が生まれる.

人間によって加えられる力 $F_{H}$ は, ブレーキ機構の働きによって $1-\alpha$ の係数を乗じた大きさがロボット（コン プライアンスを含むインピーダンスモデル）に入力され，上述した提案制御法が実現される．また，ロボット手 先の運動制御に関する遅れは, 力覚センサやサーボ系によって生じるロボットの動作遅れと, 離散化による遅れ によって表現する. 本研究では演算処理の簡単化のために, それぞれ 1 次遅れ系によって表すことができるとし ${ }^{(4)}$, システム全体を有理関数によって表現する.

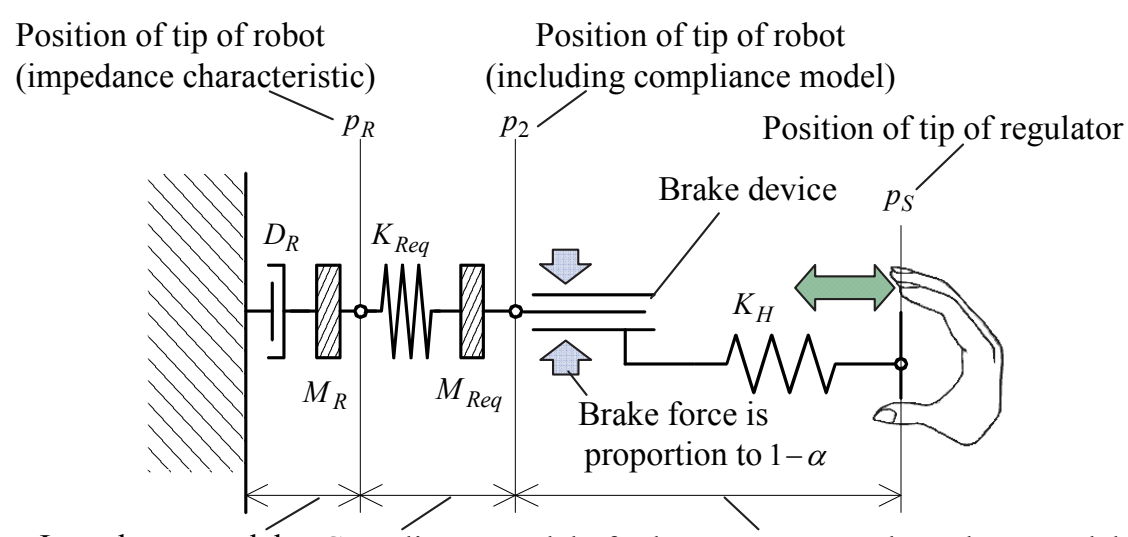

Impedance model Compliance model of robot Human and regulator model

$\Leftrightarrow$ : Force applied by human $F_{H}$

Fig.5 Dynamics model of proposed system

図 5 において, ロボットのコンプライアンスの影響を考慮すると, 実際のロボットの手先位置は $p_{2}$ で表すこと ができる. また，この手先位置 $p_{2}$ に対して，力覚情報である $F_{H}$ が制御入力として入力されることから，図 5 の 力学モデルから以下の伝達関数が導出できる.

$$
G(s)=\frac{p_{2}}{(1-\alpha) F_{H}}=\frac{M_{R} \cdot s^{2}+D_{R} \cdot s+K_{R e q}}{\left\{\left(M_{R} \cdot s^{2}+D_{R} \cdot s+K_{R e q}\right)\left(M_{R e q} \cdot s^{2}+K_{R e q}\right)-K_{R e q}{ }^{2}\right\}}
$$

ここで， $K_{R e q}$ はロボットの手先位置における等価剛性（コンプライアンスの逆数）， $M_{R e q}$ は等価慣性を表す. また， $s$ はラプラス演算子である。ささらに，ロボット手先位置の制御に関する遅れを考慮した伝達関数は以下の 式となる.

$$
\widetilde{G}(s)=\frac{M_{R} \cdot s^{2}+D_{R} \cdot s+K_{R e q}}{\left\{\left(M_{R} \cdot s^{2}+D_{R} \cdot s+K_{R e q}\right)\left(M_{R e q} \cdot s^{2}+K_{R e q}\right)-K_{R e q}{ }^{2}\right.} \cdot \frac{1}{\left(T_{R} \cdot s+1\right)\left(T_{D} \cdot s+1\right)}
$$

$T_{R}, T_{D}$ はロボットの動作による遅れ時間および制御を行う際の離散化による遅れ時間を表す．操作者または外 部環境の剛性 $K_{H}$, および操作者の反応時間による遅れ（1 次遅れ）による遅れ時間 $T_{H}$ を考慮した操作者の伝達 関数は以下の式となる.

$$
H(s)=K_{H} \cdot \frac{1}{\left(T_{H} \cdot s+1\right)} \cdot(1-\alpha)
$$

制御入力の重み付けは $\alpha$ によって制御され， $\alpha$ が大きくなるにつれ，外部環境の剛性の影響が小さくなること を意味する. また， $\alpha=1$ の時，つまり，位置偏差情報による入力のみの場合には，ロボットと外部環境の剛性 が切り離されることから，操作者とロボットの間には力学的な干渉は生じない. 式 (4) と式 (5) から, システ ムの特性方程式は以下の式によって表すことができる.

$$
1+\widetilde{G}(s) \cdot H(s)=0
$$


ロボットのコンプライアンスおよび，遅れ時間，外部環境の影響を考慮したブロック線図を図 6 に示す。一点 鎖線で囲んだループにおいて生成される入力 $\boldsymbol{K}_{V} \Delta \boldsymbol{p}$ は，上述したように仮想力であることから（図 1(b)参照)， 実際に力学的な干渉を伴う制御入力ではないので，インピーダンス制御における安定性には影響しない.

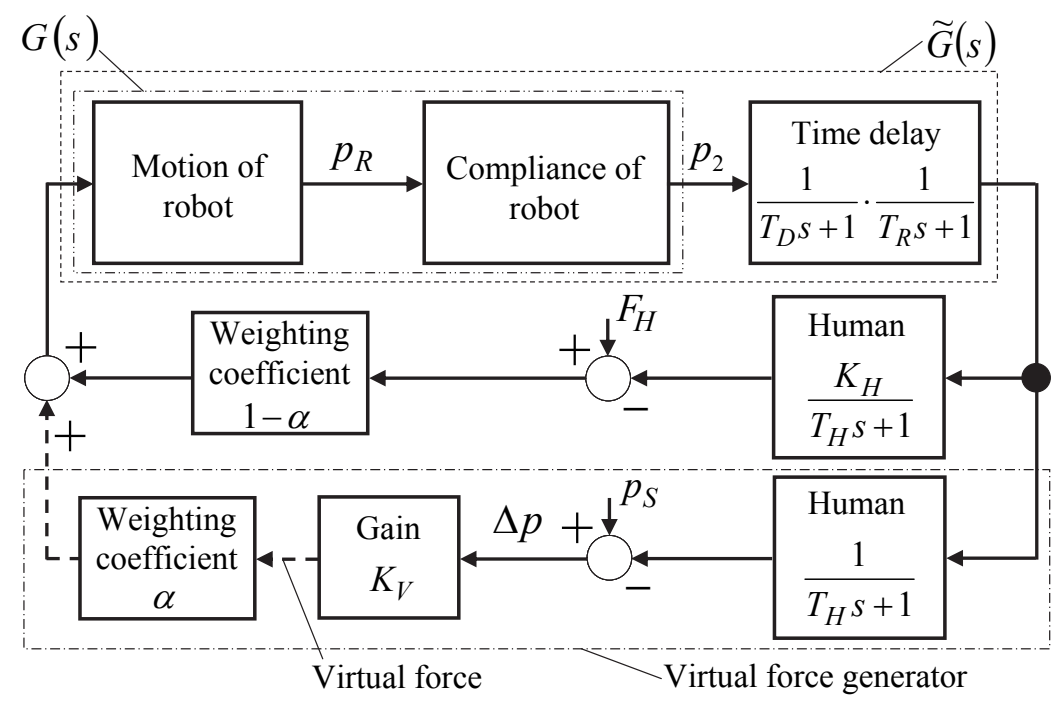

Fig.6 Block diagram of dynamics model in human-robot cooperative task system for the stability analysis

\section{5. 制御システムの安定解析シミュレーション}

\section{$5 \cdot 1$ 安定解析シミュレーション}

4 章において提案したモデルを利用して数值的な安定解析を行い，提案システムの有効性を検証する. 本章で は，操作者となる人間やロボットの運動特性，機構特性（コンプライアンス特性）の影響を含めて，実際の協調 作業に即した条件で安定解析シミュレーションを実施し, 制御パラメータによって安定性がどのように変化する かの検証を行う.

シミュレーションでは，システムの閉ループ伝達関数における極（特性方程式の根）の挙動を $s$ 平面（実数一 虚数軸からなる平面）に示した図を利用し(10)，外部環境剛性を変化させながら極の挙動を見ることで安定性を判 別し, 制御入力の重み係数 $\alpha$ を変化させることで安定性がどのように変化するかを検証する. 閉ループ伝達関数 の極を求めるためには，高次代数方程式となる特性方程式（式（6））の根を求めなければならず，その解法とし て DKA 法を用いる.

シミュレーションに用いるパラメータは次の通りである。ロボット手先のインピーダンス特性は各座標軸それ ぞれに独立して与えられるため, $x$ 軸方向に関する 1 自由度モデルを用いて, シミュレーションを行う。ロボッ トのインピーダンスパラメータのうち, 慣性係数 $M_{R}$ は $3 \mathrm{~kg}$, 粘性係数 $D_{R}$ は $90 \mathrm{Ns} / \mathrm{m}$ とする. 仮想剛性係数 $K_{V}$ は $300 \mathrm{~N} / \mathrm{m}$ とする.ロボットの手先位置の等価剛性 $K_{R e q}$ は $29000 \mathrm{~N} / \mathrm{m}(x$ 軸方向 $)$ とする ${ }^{(21)}$. 等価剛性はロボッ トの姿勢によって変化するが，実験時に用いる姿勢近傍の等価岡性を用いる，等価慣性 $M_{R e q}$ は安定性に関係す る部分の質量として $9.46 \mathrm{~kg}$ とする ${ }^{(21)}$ (提案調節器や力覚センサの質量を含む). ロボットの運動制御に関する遅 れ時間 $T_{R}$ を 0.15 秒, 制御の離散化による遅れ時間 $T_{D}$ を 0.002 秒とし, これらをあわせて 2 次遅れとする. また, 操作者の反応時間による遅れ時間 $T_{H}$ については, 時々刻々と変化し, その同定が困難であるため, 便宜上 0.15 秒とする ${ }^{(22)}$. なお, 操作者の遅れ時間が大きくなればなるほどシステムは不安定になることが知られている ${ }^{(23)}$. この上で，外部環境の影響に対するシステムの安定性を調べるために，外部環境剛性 $K_{H}$ を $10 \leq K_{H} \leq 20000$ の 範囲で変更して安定解析を行う. 制御入力の重み係数 $\alpha$ につては $0.5,1$ の 2 つ代表值に対して試行を行う. $\alpha=1$ の場合は前章で説明したように, 外部環境との力学的な干渉が存在しないことから, システムは常に安定 
となる. $K_{H}=0$ の場合は，自由空間での運動を意味していることから，接触安定問題は生じず，システムは安 定である.

\section{$5 \cdot 2$ 安定解析シミュレーション結果}

各試行の結果を図 7 に示寸。この図におけるプロットは極の動きが分かりやすいように配置したもので，パラ メータ変数 (外部環境剛性) による等間隔のものではない. また，システムの安定性に関わる極のみを表記し， それ以外の極は見や寸さのために除外している. 図 7 (a)，(b) より，外部環境剛性 $K_{H}$ が大きくなると，極が 右半平面に移動し, システムが不安定になることがわかる（極の実数部が正となる場合，システムは不安定であ る)。また，図7（a），(b) より， $\alpha$ が大きくなると，外部環境剛性とロボットの干渉具合が小さくなり，外部環 境剛性が高くても安定性に与える影響が小さくなることがわかる． $\alpha=1$ の場合については，ロボットは外部環境 と非干渉化されることからシステムが安定となることは明らかである.これらの結果は従来研究で明らかにされ た結果に沿うものであり ${ }^{(10)(11)(13)(23)}$ ，提案システムにおいては制御入力の重み係数 $\alpha$ を変化させることでシステ ムが不安定にならないよう調整可能であることが理論的に示された.

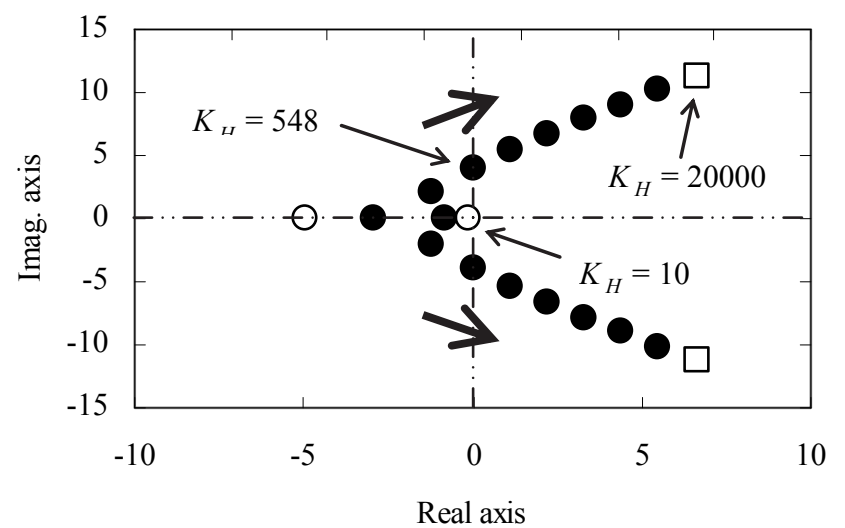

(a) $\alpha=0$

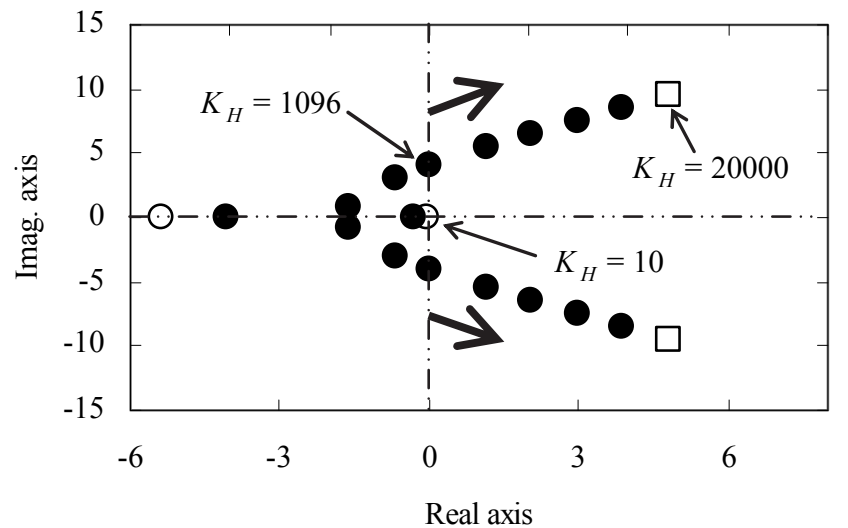

(b) $\alpha=0.5$

Fig.7 Simulation results of the stability analysis

\section{6. 安定解析検証実験}

\section{$6 \cdot 1$ 安定解析の検証実験}

前節で行った安定解析シミュレーションの有効性を確認するため，実際の実験システム（ロボット）を用いて 検証実験を実施する. 手先位置に設置された提案調節器にバネ定数が既知となる機械バネを取り付けた状態で口 ボットの制御を行い，システムが不安定（振動的になる，あるいは発散する）になるかの検証実験を行う。この 実験では, 図 8 に示寸ように, 図 5 における外部環境の剛性 $K_{H}$ をロボットの手先位置に設置した調節器に取り 付けた機械バネ (バネ定数 $K_{M}$ ) によって実現し, 実際の制御システムの安定性を検証することができる.ロボッ トの動作は図 8 のロボットの基準座標系 $\Sigma_{B}$ における $y$ 軸方向の 1 自由度に限定する．簡単のため， ロボットの インピーダンス特性の慣性係数 $M_{R}$ を $3 \mathrm{~kg}$, 仮想剛性係数 $K_{V}$ を $300 \mathrm{~N} / \mathrm{m}$ と一定に設定し, 粘性係数 $D_{R}$ を変化 させることで検証実験を行う。また，このとき $\alpha を 0$ (従来のインピーダンス制御)，0.5（提案制御則と従来の インピーダンス制御の中間制御）の２通りに関して検証を行う。

実験では, 図 8 に示寸ように剛体と仮定できる土台とロボットの手先に設置した提案調節器に機械バネを取り 付けて, ロボットの制御を開始する. ロボットのインピーダンス特性における粘性係数 $D_{R}$ を徐々に減少させ, ロボットの手先位置の振動の振幅が発散するときの粘性係数を求める. 同時に安定解析シミュレーションによっ て, 特性方程式の根の実部が 0 になるときの粘性係数を求める. 実験とシミュレーションにより得られる結果を 比較することで，提案制御則に関する実システムの安定性について検証する. 
実験には，バネ定数 $K_{M}$ が，120 N/m，214 N/m，465 N/m，760 N/m，1375 N/m となる 5 種類の機械バネを用い た. 実験姿勢でのロボットの手先位置における $y$ 軸方向の等価剛性 $K_{R e q}$ は $40000 \mathrm{~N} / \mathrm{m}$ である ${ }^{(21)}$. ロボットの先 端位置に取り付けられた力覚センサは, その機構的な剛性がロボットの機構的な剛性よりも十分に大きいため, システムの安定性には影響しないものとする。ロボットの手先位置 $p_{R}$ の運動が式 (2) のインピーダンス特性に 従うように手先位置ならびに姿勢の速度制御を行う。また， $\alpha$ が 0 のときのブレーキ力は $10 \mathrm{~N}$ とし， $\alpha$ が 0.5 のときのブレーキ力は $4.5 \mathrm{~N}$ とする. これらの制御入力の重み係数 $\alpha$ とブレーキ力の值の組み合わせについては, ロボットの運動に関する予備実験を行い決定した.

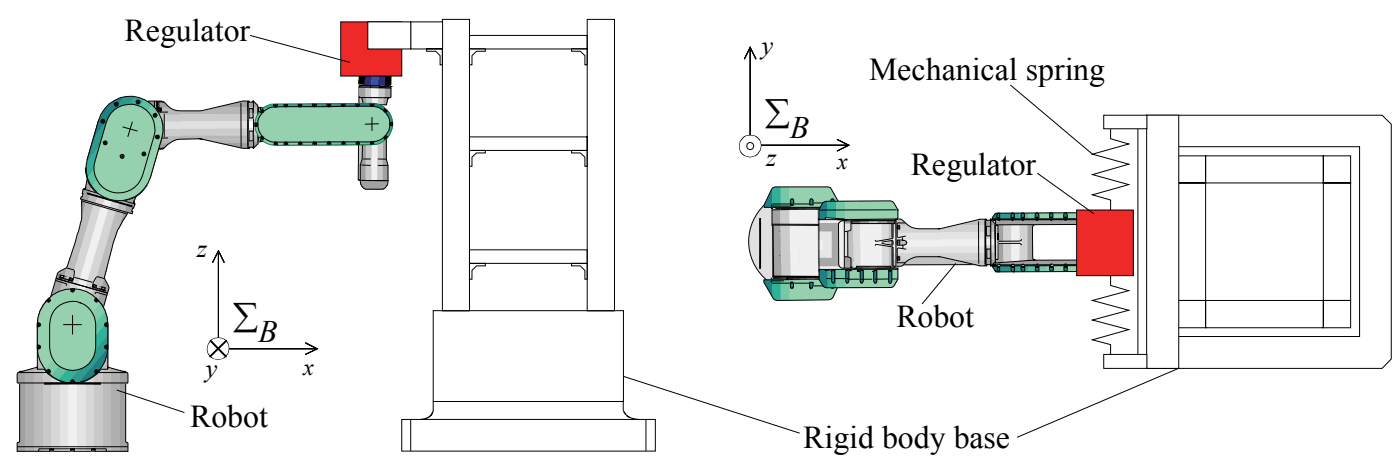

Fig. 8 Experimental setup of a verification experiment of the stability analysis

安定解析のシミュレーションでは, 等価慣性 $M_{R e q}$ を $12 \mathrm{~kg}$ とした. この等価慣性にはロボットの手先位置に 取り付けられた提案調節器や力覚センサ, 機械バネを固定するための部品の質量が含まれている（外部環境との 接続に必要な機器の質量が含まれることから, 5 章で示した等価慣性とは差がある).なお, 検証実験およびシミュ レーションでは, 外部環境の剛性係数 $K_{H}$ （実験では機械バネのバネ定数 $K_{M}$ ）のみを考慮しているため, 操作 者の反応時間 $T_{H}$ による遅れ時間を 0 秒とし, その影響を考慮していないことから, 得られた結果は反応遅れを 考慮している前章のシミュレーション結果とは大きく異なる。これは操作者の遅れ時間が安定性に大きな影響を 及ぼすことが原因であり ${ }^{(23)}$, 本実験結果は人間との協調作業には適用できない. しかし，本検証実験によってシ ミュレーションと実機実験で得られる結果の差異とその傾向については明らかにすることができる.

\section{$6 \cdot 2$ 安定解析の検証実験結果}

検証実験の結果を図 9 に示寸. 図9では,データがプロットされた場所よりも縦軸方向上側(縦軸は粘性係数 $D_{R}$ を示す）の領域でシステムは安定になる. 図 9 （a），（b）より，シミュレーションと実機実験の結果に差が生じ ていることがわかる．特に外部環境剛性が大きくなるにつれ，結果の差が大きくなっている．外部環境剛性が大 きくなると, 外部環境による反力や制御入力が大きくなり, 提案調節器自体が持つコンプライアンスの影響が大 きくなったことが原因と考えられる，さらに，モデル化できない柔軟・粘性要素の影響に加えて，反力や制御入 力が大きくなるにつれて非線形的にこれらの要素の影響が大きくなったことが一因と予想される（コンプライア ンス等のモデリングを線形系で行っているため). ただし, システムに含まれるコンプライアンスや粘性要素は, システムを安定にする働きがあることから (23), 結果の差異については安定側に働くことが分かっている.

このことを踏まえて考えると, いずれの場合においても, シミュレーション結果の方が実験結果よりも安定領 域側（図中のプロット点よりも上部の領域）に分布しており，実質的に安全率を見込んだ結果となっていること に加えて，両結果には同様の傾向が見られたので，シミュレーション結果を参考にして制御システムが安定とな るロボットのインピーダンス特性や, 制御パラメータを設定することができる. また, 図 9 (b) の実機実験の結 果において，バネ定数 $K_{M}$ が $120 \mathrm{~N} / \mathrm{m}$ のときのプロットが存在しないが，これは粘性係数を小さくしてもロボッ トが不安定にならなかったためである.

以上の結果から, 提案システムでは制御入力の重み係数 $\alpha$ とブレーキ力のパラメータ調整により, システムの 安定性を確保できることがわかった。従来のインピーダンス制御では，システムの安定化のためにエネルギの消 
散を司る粘性係数を大きく寸る必要があったが，提案システムでは粘性係数を小さく抑えても安定になることが 理論的・実験的に明らかになった．この結果は，協調作業におけるインピーダンス特性の粘性の影響を少なくで きることを意味しており（粘性係数が小さくても安定であるため), 操作者の運動が阻害されることなく, より直 感的な作業を行えることを示している.

$\times$ Simulation result $\bigcirc$ Experimental result

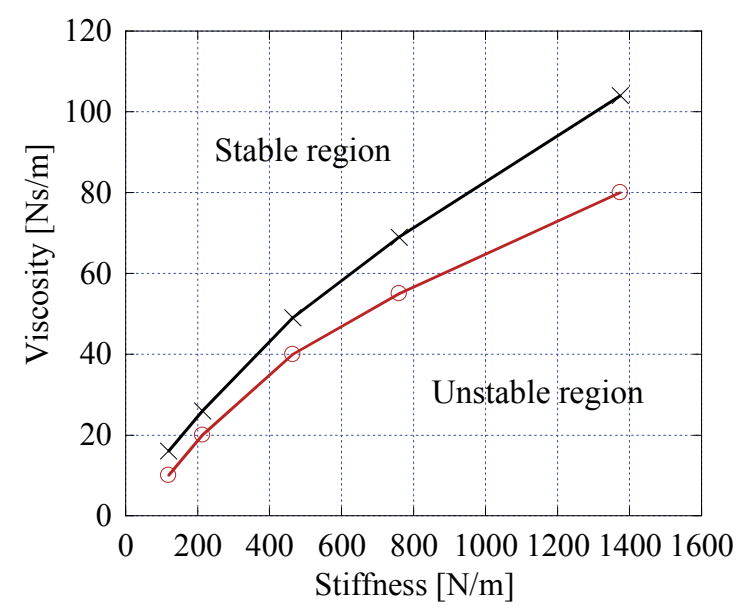

(a) Case of $\alpha=0$ $\times$ Simulation result $\bigcirc$ Experimental result

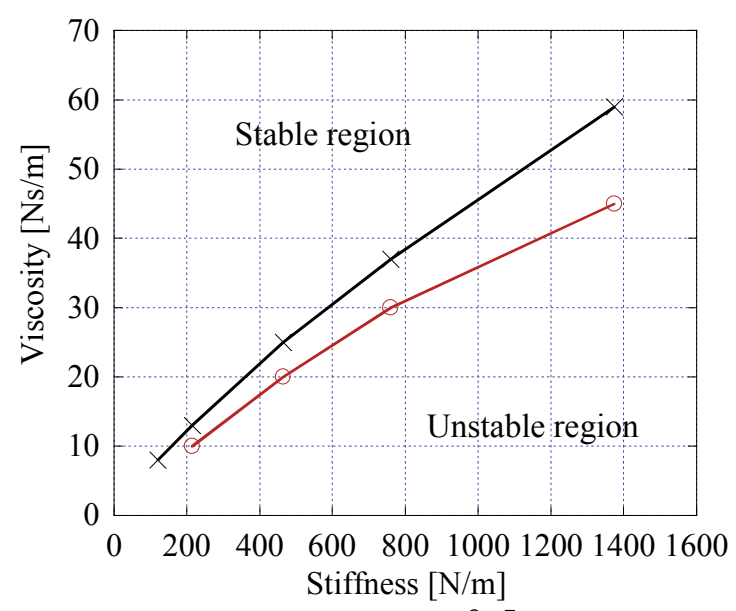

(b) Case of $\alpha=0.5$

Fig.9 Results of verification experiments of the stability analysis

\section{7. 協調作業実験}

\section{$7 \cdot 1$ 外部環境との接触実験・精密はめあい作業実験}

提案調節器を用いて, 高剛性環境との接触を含む, 人間一ロボットの力学的協調作業である運搬一接触作業を 行い, 調節器の効果を確認する. 実験システムを図 10 に示す. 被験者は調節器のハンドル部に取り付けられた作 業対象物である peg 部品を操作し, 運搬作業の後に外部環境との接触を伴う作業を行う. peg 部品を挿入する hole 部品は, 機械バネを介して高剛性環境に取り付けられており, 作業者は作業対象の動特性として, 機械バネのバ ネ特性を感じる，認識することができるようになっている．また， hole 部品を直接的に高剛性環境に接続するこ ともでき，外部環境剛性を変化させて実験を行うことができる．実験で用いる peg 部品は直径 $20_{-0.009}^{0} \mathrm{~mm}$ （寸法 公差 h5), hole 部品は直径 $20_{0}^{+0.021} \mathrm{~mm}$ （寸法公差 $\mathrm{H} 7$ ), 奥行き（深さ）が $40 \mathrm{~mm}$ である.

まず，実験(i)として，外部環境との接触実験を行う. 図 10 に示寸軌跡(i)ならびに図 10(c)の通りに peg 部品を 運搬し, hole 部品の縁と接触させて押しつけを行うことで, 接触状態下において外部環境の認識が可能かどうか, そのときの安定性がどうかを検証し，提案制御法の有用性を確認する。運搬作業ではインピーダンス制御を用い てパワーアシスト効果（仮想的な動特性を付与して運搬作業を実現する）を利用し，接触後に提案制御法への切 り替えを行う。そして, 接触作業終了後には再びインピーダンス制御に遷移し, peg 部品の運搬を行う。なお, 本実験では peg と hole 部品の接触を通電によって検知し，接触中は提案制御法に切り替えを行う.

次に，実験(ii)として，図 10(d)に示すような精密な挿入作業（組み立て作業）を伴う実験を行うため, インピー ダンス制御を用いて peg 部品を hole 部品の四角穴部の内部まで運搬し（四角穴寸法は peg 部品径に比べて大きい ため接触しない), その後, 両部品を接触させて, 接触状態を保ちながら長穴に沿って peg 部品を移動させ, 長穴 の右側端部と peg 部品を接触させた状態で押しつけ, 拘束条件下においても外部環境の認識が可能かを検証する. 本実験では操作者が接触動作前後の任意のタイミングで提案制御法に切り替えを行い, 離脱動作直後にインピー ダンス制御に戻す。なお， $\mathrm{H} 7 / \mathrm{h} 5$ の寸法公差（最大間隙は $0.03 \mathrm{~mm}$ ）となる精密な間隙での接触作業や，同寸法公 差下での peg 部品の移動作業は, 操作者単独で行う場合においても技能の発現を必要とする比較的難しい作業で あることから，ロボットとの協調作業においてこのような作業が実現できれば，様々な応用が可能になると予想 できる. 
実験における，ロボット手先のインピーダンスパラメータは，慣性係数 $M_{R} を 3 \mathrm{~kg}$, 粘性係数 $D_{R} を 70 \mathrm{Ns} / \mathrm{m}$, $90 \mathrm{Ns} / \mathrm{m}$ の 2 種類, 仮想剛性係数 $K_{V}$ を $300 \mathrm{~N} / \mathrm{m}$ に設定する. ロボットが接触する外部環境の剛性となるバネ定数 $K_{M}$ は, $465 \mathrm{~N} / \mathrm{m}, 760 \mathrm{~N} / \mathrm{m}, 1375 \mathrm{~N} / \mathrm{m}$ ，剛体（アルミフレームの剛性と等価）の 4 種類とした. 試行の種類な らびに提案制御法の制御入力の重み係数 $\alpha$ とブレーキ力のパラメータは以下のように設定する.

試行(i) 従来のインピーダンス制御（ $\alpha=0)$ ，ブレーキ力は $10 \mathrm{~N}$.

試行(ii) 操作者の手先に追従する制御（ $\alpha=1 ）$, ブレーキ力は $0 \mathrm{~N}$.

試行(iii) 試行（i）と（ii）の 2 つの制御を合わせた制御（ $\alpha=0.5 ）$, ブレーキ力は $4.5 \mathrm{~N}$.

なお，インピーダンスパラメータの設定や実験の試行過程によってはシステムが不安定になり，危険を伴う恐 れがあることから，被験者はロボットとの協調作業に慣れた 2 名の熟練者とした.

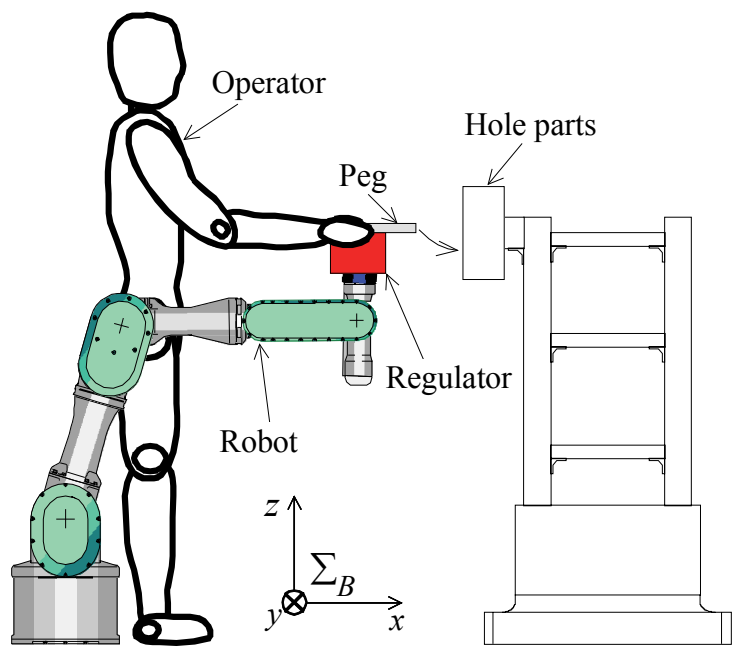

(a) Overview of peg-insertion task experiment

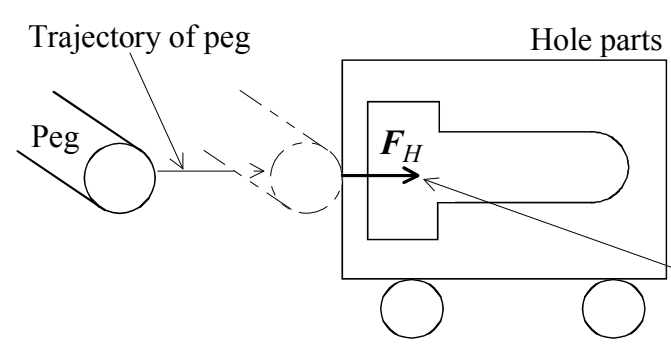

(c) Overview of experiment (i)

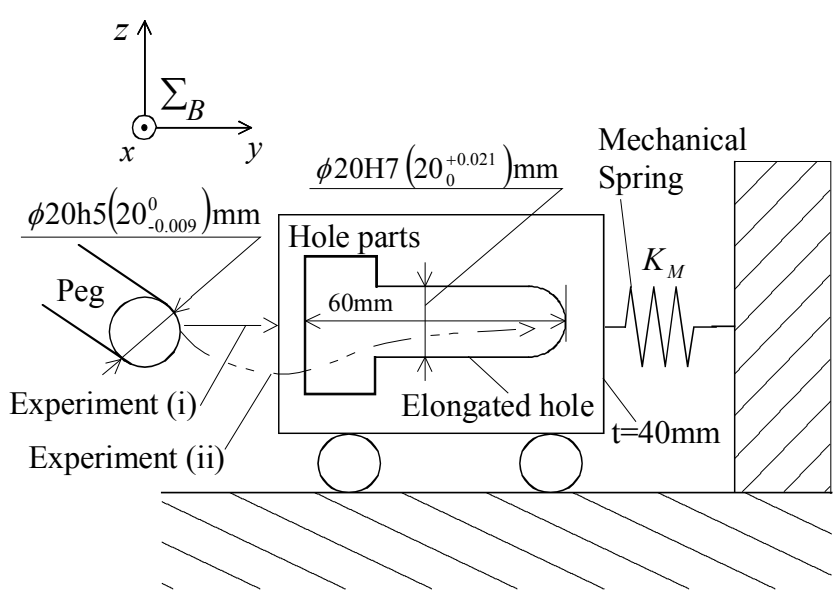

(b) Peg and hole parts with external environment

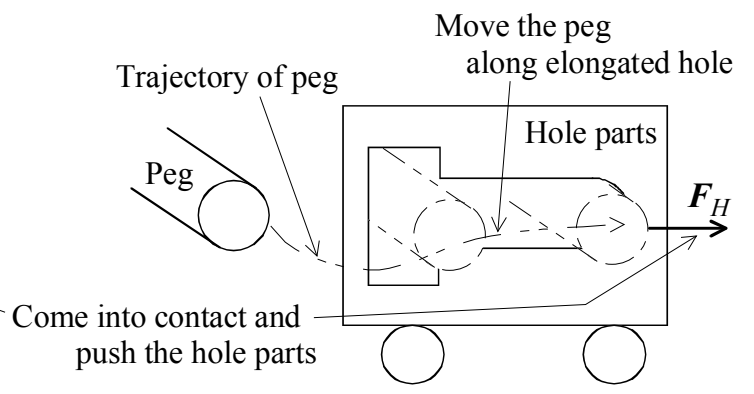

(d) Overview of experiment (ii)

Fig.10 Overview of experimental trials in human-robot cooperative task

\section{$7 \cdot 2$ 接触実験・精密はめあい作業実験結果と考察}

実験(i)の代表的な結果を図 11 (粘性係数 $D_{R}: 70 \mathrm{Ns} / \mathrm{m}$, バネ定数 $K_{M}: 1375 \mathrm{~N} / \mathrm{m}$ ), 図 12 (粘性係数 $D_{R}: 90 \mathrm{Ns} / \mathrm{m}$, バネ定数 $K_{M}$ : 剛体) に示す. ロボットの手先軌道と検出された力, peg と hole 部品の接触フラグについて記載 している. いずれも接触後の押しつけ方向である $y$ 軸方向に関するデータである.

試行(i) のインピーダンス制御（ $\alpha=0 ）$ の結果については, 図 11(a)に示すように, 接触が開始された 5 秒付近 からロボットの手先軌道と検出された力が振動的になり, 特に 10 秒あたりではインパルス状の大きな力が加わり, 押しつけ動作が円滑に遂行できていないことがわかる．また，操作者の主観的な評価ではあるが，ロボットの運 動に付与したインピーダンス特性の影響によって, 作業中に外部環境のバネ定数を認識することができなかった との感想が得られている. なお, 安定解析シミュレーションと実際の実験における安定性との整合性については, 人間の遅れ時間が一定ではないことや，外部環境との接触・拘束状態が安定しなかったことから，両結果を完全 に一致させることは困難であった（以後の実験に関しても同様）. 
試行(iii)の制御（ $\alpha=0.5 ）$ の代表的な結果については，図11(b)に示すように，先述したインピーダンス制御の 結果と比べて振動的になっていないことがわかる. 接触検知と同時に制御法が切り替わり，式 (2) で示した制御 則通りにインピーダンス制御の重み付けが半分になることからシステムの安定性が確保され，不安定にはならな い状況で押しつけ作業を遂行することができている．しかし，操作者の主観的な評価では，作業中に若干の振動 が生じていたことから，外部環境のバネ定数を明確には認識することができず，慣性と粘性からなるインピーダ ンス特性の存在を感じたとの感想が得られている.これはロボットへの制御入力として実際の力が入力されるこ とに加えて, ブレーキ力の発生によって人間とロボットの運動に干渉が生じていることから，ロボットの運動と して付与したインピーダンス特性が操作者の運動に対しても影響を及ぼしていると推測できる.

試行(ii) の制御（ $\alpha=1 ）$ の代表的な結果については，図11(c)に示すように，検出された力には安定性に影響を 及ぼすような振動的な現象は見られず，ロボットの手先軌道にも振動が現われていないことがわかる．操作者の 主観的な評価によれば，作業中の振動は生じず，外部環境のバネ定数をはっきりと認識することができたとの感 想が得られている.

これらの結果については，定性的，主観的な評価にとどまるものの，提案制御法によって外部環境との接触条 件下においても外部環境の認識が可能であることが示された. しかし, 作業中に $5 \mathrm{~N}$ ほどの力が検出されており， ロボットの運動と操作者（外部環境）の動特性の完全な非干渉化はできていない. これは高剛性となる hole 部品 との接触において, 調整器の機構にひずみが生じ摺動部が押しつけられたことで引きずりが生じたことや, リニ アガイドレールの摩擦の影響（静止摩擦は約 $2 \mathrm{~N}$ ）によるものである. また，制御の切り替え直後には，電磁石を 利用したブレーキ機構の応答性の遅れが原因となり, より大きな力が生じている.ただし， $\alpha=0$ の場合には, 検出された力は制御入力として利用されないことから, ロボットの運動制御に影響はない. 現状の調整器では, 機器調整の限界から低干渉状態しか実現できないため, 不必要な干渉の低減やブレーキ機構の応答性の改良につ いては今後の課題としたい.

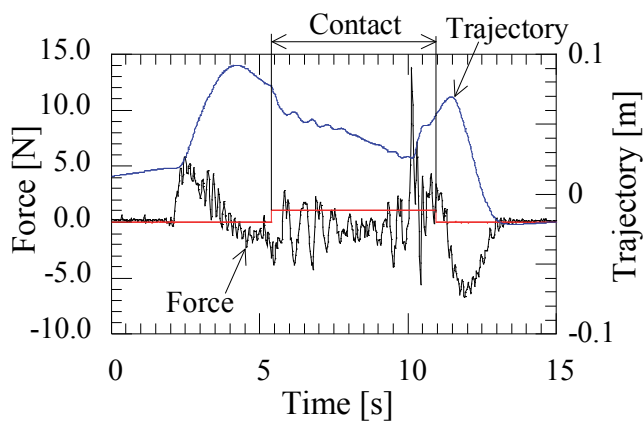

(a) $\alpha=0$ (Impedance control)

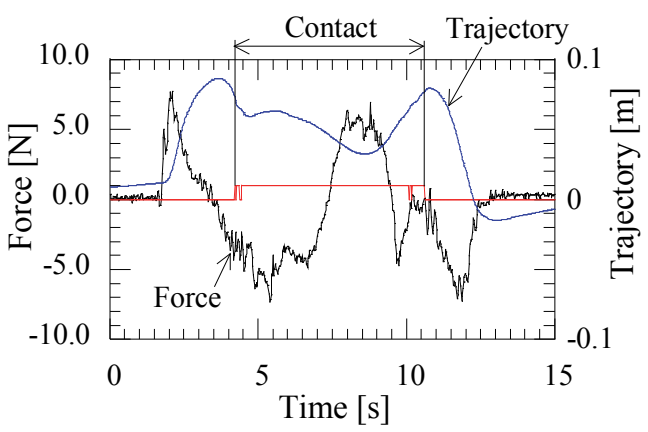

(c) $\quad \alpha=1$ (Decoupling state)

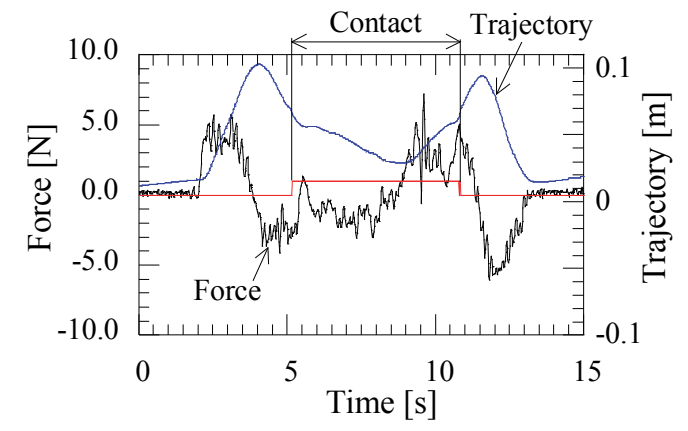

(b) $\alpha=0.5$ (Hybrid control)

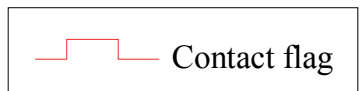

Fig.11 Experimental results of human-robot cooperative task which comes into contact with the external environment (y-axis, $\left.K_{M}=1375 \mathrm{~N} / \mathrm{m}, D_{R}=70 \mathrm{Ns} / \mathrm{m}\right)$ 
実験(i)において，hole 部品を剛体に接続した場合の結果（図 12）に関する考察を行う。図 12(a)の試行(i) のイ ンピーダンス制御（ $\alpha=0 ）$ では，システムが不安定になり，押しつけ動作が遂行できなかった. 図 12(b)の試行 (iii)の制御（ $\alpha=0.5 ）$ においてもロボットの手先軌道が振動的になり, hole 部品との接触は維持できるものの, カデータは振動状態が続いている. しかし, 振動的な力データについては, $\alpha=0$ と比べて大幅に減少し, 振動 周期も若干長くなっていることがわかる. これは設定した制御則通りに, 制御入力の重み係数 $\alpha$ とブレーキ力の 調整によって，外部環境からの影響を減じることが可能となったためである. 図 12(c)の試行(ii) の制御 $(\alpha=1)$ では, 試行(i), 試行(iii)とは異なりシステムが不安定になっておらず, 安定した押しつけ動作が実現されており, 操作者も外部環境が剛体であることを認識できていた.

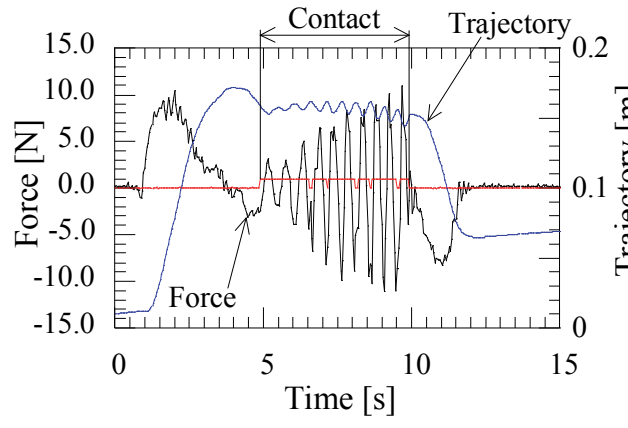

(a) $\quad \alpha=0$ (Impedance control)

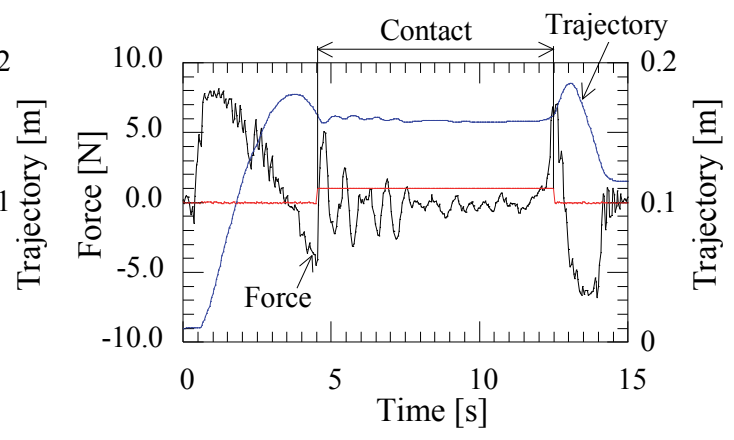

(b) $\alpha=0.5$ (Hybrid control)

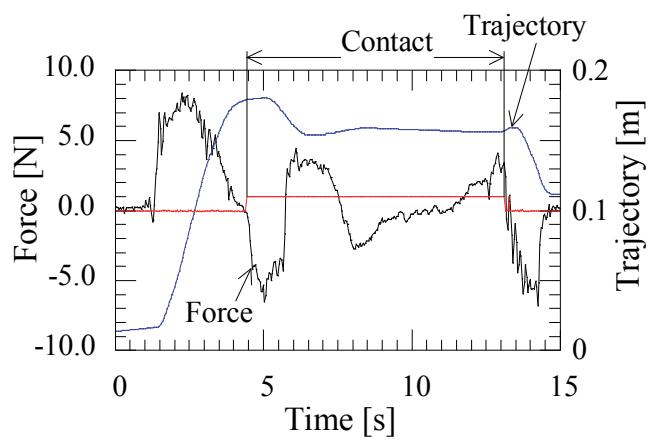

(c) $\quad \alpha=1$ (Decoupling state)

Fig.12 Experimental results of human-robot cooperative task which comes into contact with the external environment (y-axis, $K_{M}=$ Rigid body, $D_{R}=90 \mathrm{Ns} / \mathrm{m}$ )

他の実験パラメータの試行についても同様の結果が得られており，主観的評価において，試行(ii) の制御以外 では，インピーダンス特性の影響から外部環境の明確な認識は困難であるとの結果が得られた。試行(ii) の制御 試行においては，どの条件においても外部環境剛性である機械バネのバネ定数を認識することができたとの感想 が得られている.

次に, 実験(ii)の代表的な結果を図 13,14 (粘性係数 $D_{R}: 90 \mathrm{Ns} / \mathrm{m}$, バネ定数 $K_{M}$ ：剛体）に示す. ロボット の手先軌道と検出された力, peg と hole 部品の接触動作直前と離脱動作直後に発生する制御法切り替えフラグに ついて記載している．図 13 は接触後の移動方向・押しつけ方向である $y$ 軸方向に関するデータ, 図 14 は挿入方 向である $x$ 軸方向に関するデータを示している.

図 13(a)，14(a)の試行(i) のインピーダンス制御（ $\alpha=0 ）$ では, peg と hole 部品の接触直後にシステムが不安 定になり, 長穴への挿入さえできない状態であった. 図14(a)には接触後の移動方向への変位が生じていないこと が示されており, peg と hole 部品が接触しただけで作業が終了している. 図 13(b)，14(b)の試行(iii)の制御 $(\alpha=0.5)$ においても大きな振動が続くカデータが検出されている.このため, ロボットの手先軌道が振動的になり, 接触 後の移動はある程度は実現できているものの, ほぼ不安定状態下での作業となった. 本試行ではロボットの振動 状態が続いており, 安定性の問題から危険になる恐れがあったため, インピーダンス制御に復帰させないまま, 実験を終了させた. 図 13(c)，14(c)の試行(ii) の制御（ $\alpha=1 ）$ では, 安定状態で peg と hole 部品が接触し, 長穴 
部における移動や押しつけ動作も実現できている．また，操作者の主観的評価も良好で，外部環境が剛体である ことを認識できていた。

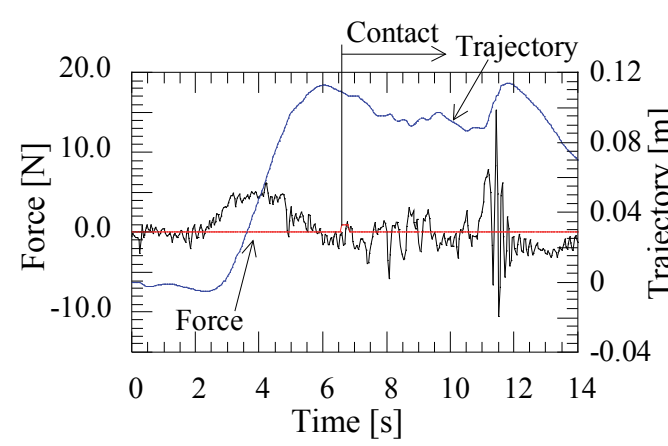

(a) $\alpha=0$ (Impedance control)

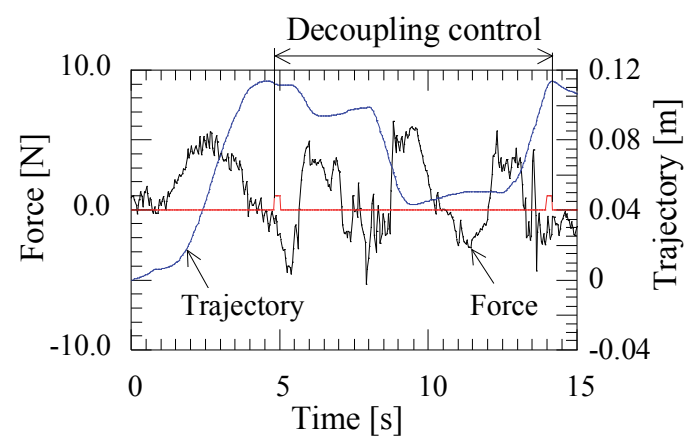

(c) $\quad \alpha=1$ (Decoupling state)

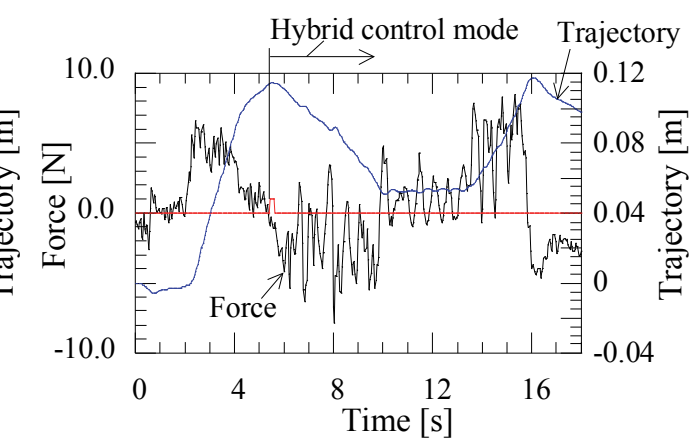

(b) $\alpha=0.5$ (Hybrid control)

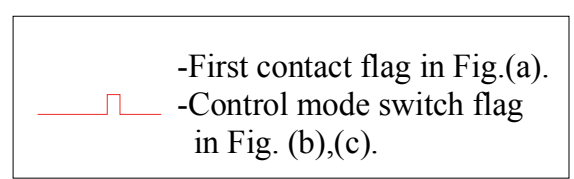

Fig.13 Experimental results of human-robot cooperative peg-insertion tasks (y-axis, $K_{M}=$ Rigid body, $D_{R}=90 \mathrm{Ns} / \mathrm{m}$ )

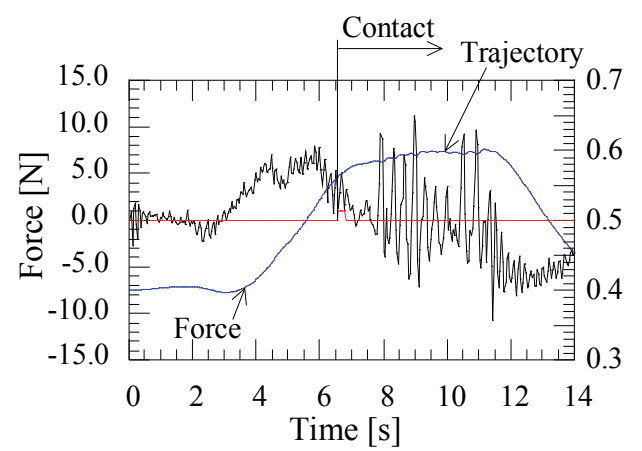

(a) $\alpha=0$ (Impedance control)

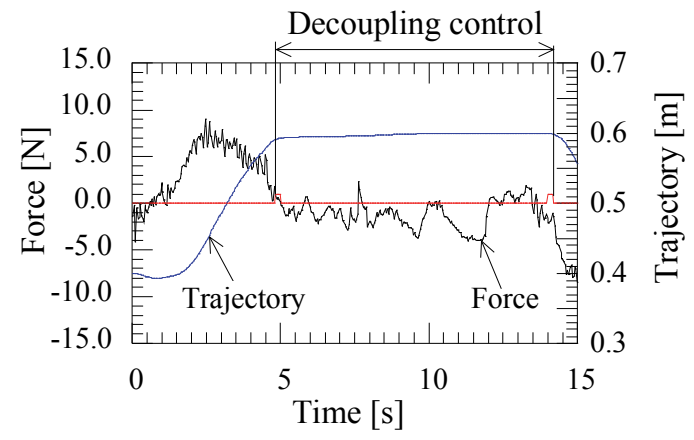

(c) $\alpha=1$ (Decoupling state)

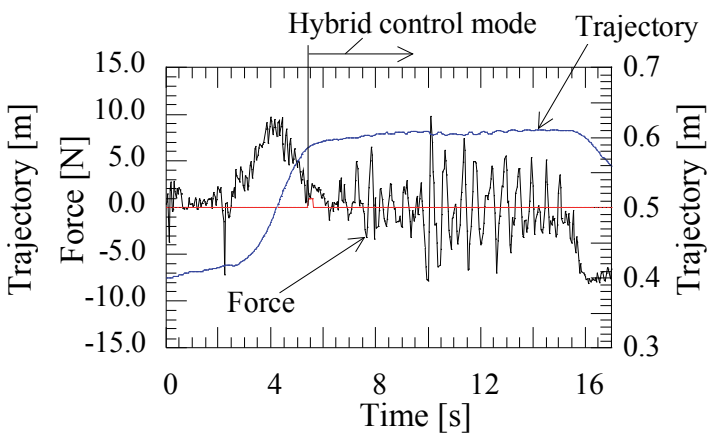

(b) $\alpha=0.5$ (Hybrid control)

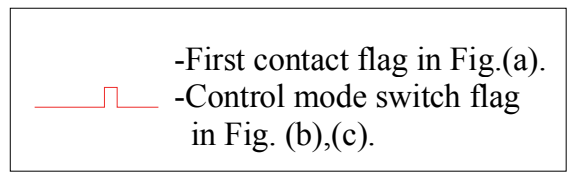

Fig.14 Experimental results of human-robot cooperative peg-insertion tasks (x-axis, $K_{M}=$ Rigid body, $D_{R}=90 \mathrm{Ns} / \mathrm{m}$ ) 
他の実験パラメータの試行については，実験(i)の結果と同様に，試行(ii) の制御以外では，システムの安定性 の問題から作業を遂行できないだけでなく, 操作者による外部環境の明確な認識は困難であったとの結果が得ら れた. 試行(ii) の制御においても剛体との接触作業においては, インピーダンス制御の接触安定問題がクリティ カルになることがわかった.

以上の結果より，提案システムの有効性を示すことができた．提案制御法によって提供される作業環境は，仮 想的に与えられたインピーダンス特性下での作業とは異なり，作業対象物の持つ固有な動特性に基づく作業が可 能になることから，作業者が持つ技能に基づく直感的な作業が実現できることがわかった．制御パラメータの設 定によっては，接触作業においてインピーダンス制御のパワーアシスト効果を利用できないが，技能の発現が必 要な作業などにおいては提案システムが有用であると考えられる．ただし，今回の実験は準静的に近い速度域で 作業を実施していることに加えて, 設定したインピーダンス特性についても接触作業を対象とした応答性の低い パラメータであることから，作業速度を上昇させる場合には，新たな検証とパラメータ設定が必要である.

また，インピーダンス制御のパワーアシスト効果を利用したい場合，あるいは，仮想的な動特性をある程度の 範囲で付与したい場合には, 作業対象の外部環境剛性にもよるが, 切り替え制御や試行(iii)における制御のように, 重み係数 $\alpha$ とブレーキ力の值の調整によって対応できる. このように，提案システムを用いることにより，作業 者の意図や好みに応じた制御を提供することができ，従来のインピーダンス制御では実現できなかった作業への 応用が可能になることが示された，なお，制御システムの効果や有効性に関する定量評価，安定解析シミュレー ションと実際の実験結果との整合性に関する検討については今後の課題としたい.

\section{8. 結 語}

本研究では, 操作者とロボットの動特性の干渉具合を調節する調節器の開発を行った. さらに，人間とロボッ トの接触作業において，安定した制御を実現するロボットの運動制御法を提案した．また，安定解析シミュレー ションによって，提案制御システムの外部環境との接触安定性を明らかにし，検証実験によって，制御パラメー タの設定に解析結果が有効であることを示した．さらに，高岡性環境との接触を含む，人間とロボットによる協 調作業実験を行い，提案システムが高剛性環境に対する接触作業に適用可能であること，そして，接触作業中の 外部環境の動特性を操作者が直接的に認識できるようになることを示した.

今後の課題としては, 提案調節器および運動制御システムの回転運動への自由度拡張や装置の小型化, ブレー キ力と重み係数 $\alpha$ の設定・調整方法の確立などが挙げられる.

\section{謝 辞}

なお，本研究の一部は日本学術振興会 科学研究費補助金 基盤研究（B）（課題番号：21360120）, ならびに, 基盤研究 (C) （課題番号：24560312）の援助を受けた。ここに記して謝意を表する.

\section{文献}

(1) Santis, A.D., Siciliano, B. Luca, A.D., Bicchi, A., "An atlas of physical human-robot interaction", Mechanism and Machine Theory, Vol. 43, No. 3 (2008), pp. 253-270.

(2) Pervez, A., Ryu, J., "Safe physical human robot interaction-past, present and future", Journal of Mechanical Science and Technology, Vol. 22, No. 3 (2008), pp. 469-483.

(3) 原進, “サーボ搬送制御とインピーダンス制御のなめらかな切り換えによる台車の位置決め”, 日本機械学会論文集 C 編，Vol. 70, No. 689 (2004), pp. 127-134.

（4）池浦良淳，“人間とロボットによる協調作業”，システム/制御情報，Vol. 44, No. 12 (2000), pp. 682-687.

(5) Kikuuwe, R., Fujimoto, H., "Proxy-Based Sliding Mode Control for Accurate and Safe Position Control", IEEE International Conference on Robotics and Automation (2006), pp. 25-30.

（6）山田陽滋, 鴻巣仁司, 森園哲也, 梅谷陽二, “自動車組み立て工程における搭載作業のためのスキルアシストの提 案”, 日本機械学会論文集 C 編, Vol. 68, No. 666 (2002), pp. 161-168. 
(7) 榎本敦子, 杉本浩一, 松本義雄, “マクロマイクロ機構のインピーダンス制御”, 日本機械学会論文集 C 編, Vol. 66, No. 646 (2000), pp. 119-126.

(8) Kazerooni, H., "Human Power Extender: An Example of Human-Machine Interaction via the Transfer of Power and Information Signals", International Workshop on Advanced Motion Control (1998), pp. 565-572.

(9) Al-Jarrah, O.M., Zheng, Y.F., "ARM-MANIPULATOR COORDINATION FOR LOAD SHARING USING VARIABLE COMPLIANCE CONTROL”, IEEE International Conference on Robotics and Automation (1997), pp. 895-900.

(10) 榊泰輔, 舘暲, “インピーダンス制御の接触安定性についての一考察”, 日本ロボット学会誌, Vol. 12, No. 3 (1994), pp. 489-496.

(11) Hogan, N., "On the Stability of Manipulators Performing Contact Tasks", IEEE Journal of Robotics and Automation, Vol. 4, No. 6 (1988), pp. 677-686.

(12) Whiney, D.E., "Quasi-Static Assembly of Compliantly Supported Rigid Parts", Journal of Dynamic Systems, Measurement, and Control, Vol. 104, No. 1 (1982), pp. 65-77.

(13) Surdilovic, D., "Contact Stability Issue in Position Based Impedance Control: Theory and Experiments", IEEE International Conference on Robotics and Automation (1996), pp. 1675-1680.

(14) Tsumugiwa, T., Yokogawa, R., Hara, K., "Variable Impedance Control with Virtual Stiffness for Human-Robot Cooperative Peg-in-Hole Task", IEEE International Conference on Intelligent Robotics and Systems (2002), pp. 1075-1081.

(15) Doulgeri, Z., Iliadis, G., "Stability of a contact task for a robotic arm modeled as a switched system", IET Control Theory, Vol. 1, No. 3 (2007), pp. 844-853.

(16) 武居直行, 野畑茂広, 藤本英雄, “安定した接触を実現するアドミッタンス制御手法”, 日本ロボット学会誌, Vol. 26, No. 6 (2008), pp. 635-642.

(17) Albu-Schaffer, A., Ott, C., Hirzinger, G., "A Unified Passivity-based Control Framework for Position, Torque and Impedance Control of Flexible Joint Robots", The International Journal of Robotics Research, Vol. 26, No. 1 (2007), pp. 23-39.

(18) Lawrence, D.A., "Stability and Transparency in Bilateral Teleoperation", IEEE Transactions on Robotics and Automation, Vol. 9, No. 5 (1993), pp. 624-637.

(19) Newman, W.S., Branicky, M.S., Podgurski, H.A., Chhatpar, S., Ling Huang, Swaminathan, J., Hao Zhang, "Force-Responsive Robotic Assembly of Transmission Componets", IEEE International Conference on Robotics and Automation, Vol. 3 (1999), pp.2096-2102.

(20) Kazerooni, H., "Direct-drive active compliant end effector (active RCC)", IEEE Journal of Robotics and Automation, Vol. 4, Issue. 3(1988), pp.324 - 333.

(21) 積際徹, 横川隆一, 原敬, “多自由度を有する垂直多関節型ロボットのコンプライアンスの計測（7 自由度を有す るロボット PA-10 への適用)”, 日本機械学会論文集 C 編，Vol. 69, No. 688 (2003), pp. 153-160.

(22) Ashoke, B., Shikha, D., Sudarsan, B., "REACTION TIME WITH RESPECT TO THE NATURE OF STIMULUS AND AGE OF MALE SUBJECTS", Journal of Sport and Health Research, Vol. 2, No. 1 (2010), pp. 35-40.

(23) 積際徹, 㴊上康徳, 神吉厚之, 横川隆一, 吉田和信, “人間とロボットの協調作業系におけるロボットのインピー ダンス制御の安定性解析に関する一考察”，日本機械学会論文集 C 編，Vol. 71, No. 707 (2005), pp. 2267-2272. 